\title{
Guidelines for the safe administration of inhaled nitric oxide
}

\author{
O I Miller, D S Celermajer, J E Deanfield, D J Macrae
}

\begin{abstract}
Inhaled nitric oxide (NO) is a selective pulmonary vasodilator, potentially useful in the treatment of pulmonary hypertension and ventilation-perfusion mismatch. High doses of inhaled $\mathrm{NO}$ and its oxidative product nitrogen dioxide $\left(\mathrm{NO}_{2}\right)$ may cause acute lung injury. Using a standard infant ventilator, ventilator circuit and test lung, an administration and monitoring strategy has been defined for inhaled NO and these observations validated in eight ventilated infants. In $90 \%$ oxygen, doses of inhaled $\mathrm{NO} \geqslant 80$ parts per million may result in toxic $\mathrm{NO}_{2}$ concentrations.

(Arch Dis Child 1994; 70: F47-F49)
\end{abstract}

Healthy endothelium controls vasomotor tone ${ }^{1}$ by producing vasoactive substances, including the endothelium derived relaxing factor, endogenous nitric oxide (NO).$^{23} \mathrm{NO}$ is synthesised from $\mathrm{L}$-arginine in the endothelial cell ${ }^{4}$ and acts locally on the vascular smooth muscle cell to produce vasodilation.

In experimental pulmonary vasoconstriction, inhaled exogenous NO acts directly on pulmonary vascular smooth muscle to induce vasorelaxation. ${ }^{5}$ Furthermore, inactivation of inhaled NO by avid binding to haemoglobin ${ }^{6}$ precludes a systemic vasoactive effect. In the

Dr O I Miller, Intensive Care Unit, The Children's Hospital, Camperdown, NSW 2050, Australia.

Accepted 18 August 1993 clinical setting, NO is inexpensive, easy to administer in a respiratory gas mixture, and has been reported to cause selective pulmonary vasodilatation in neonates with persistent pulmonary hypertension, ${ }^{78}$ children with congenital heart disease, ${ }^{9-12}$ and adults with pulmonary hypertension ${ }^{13}$ or the adult respiratory distress syndrome. ${ }^{14}$

Serious toxicity may result from high doses of inhaled NO. ${ }^{15}$ More importantly, however, in the presence of oxygen, NO is converted to nitrogen dioxide $\left(\mathrm{NO}_{2}\right)$, which may cause pneumonitis, pulmonary oedema, or emphysema. ${ }^{16}$ The Centers for Disease Control have recommended an upper limit exposure to $\mathrm{NO}_{2}$ of 5 parts per million (ppm) in an eight hour period. ${ }^{17}$ Theoretical ${ }^{18}$ and in vitro $^{19}$ work based on the rate formula for oxidation of $\mathrm{NO}$ to $\mathrm{NO}_{2}$ suggests such rapid production of $\mathrm{NO}_{2}$, that clinical use of $\mathrm{NO}$ would seem impractical, yet recent clinical reports have not uniformly commented on this important toxic product. We aimed to define safe and effective guidelines for delivering inhaled $\mathrm{NO}$ and monitoring $\mathrm{NO}_{2}$ concentrations in ventilated infants.

\section{Methods}

Medical grade NO (1000 ppm) was obtained in a balance of nitrogen (BOC Special Gases). Studies were performed using a continuous flow, pressure limited ventilator (Babylog 8000 , Dräger Ltd) set to simulate neonatal ventilation, a standard disposable ventilator circuit with a compressible volume of $150 \mathrm{ml}$ (Model 6057, Intersurgical), a servocontrolled humidifier with a reservoir volume of $120 \mathrm{ml}$ (Model MR730, Fisher and Paykel) and a 50 $\mathrm{ml}$ silicone test lung. NO gas was titrated via a calibrated nitrogen flowmeter (KDG Mobrey Instruments) into the inspiratory limb of the circuit, while circuit gas was continuously aspirated for analysis of $\mathrm{NO}$ and $\mathrm{NO}_{2}$ by chemiluminescence (TEI 42, Thermo Electron Ltd).

Three reproducible sites $\mathrm{A}, \mathrm{B}$, and $\mathrm{C}$ (figure) along the ventilator circuit were chosen for gas administration and/or analysis. Site B was used as the reference point for other comparisons as it was immediately adjacent to the patient connection which was accomplished via low $(<2 \mathrm{ml})$ dead space $8.5 \mathrm{~mm}$ connectors. Analysis for inspired oxygen fraction was performed at $\mathrm{B}$. Peak $\mathrm{NO}$ and $\mathrm{NO}_{2}$ concentrations were recorded at steady state. All results are the means of three recordings.

As the standard set up, ventilator gas flow was set at $10 \mathrm{1} / \mathrm{min}$ with an inspired oxygen of $90 \%$, NO was added at site A to achieve a NO
Ventilator circuit for inhaled $\mathrm{NO}$ delivery and $\mathrm{NO} / \mathrm{NO}_{2}$ analysis during continuous flow
ventilation. $A=$ inspiratory limb administration site, $B=$ analysis site at patient connection, $C=$ expiratory limb analysis site, $P E=$ proximal extreme, $H=$ humidifier, $\mathrm{O}_{2}=$ oxygen,
$\mathrm{N}_{2}=$ nitrogen. 
concentration of $40 \mathrm{ppm}$. Analysis for $\mathrm{NO}$ and $\mathrm{NO}_{2}$ was performed at site $\mathrm{B}$. An inspired oxygen of $100 \%$ is not achievable due to dilution of the inspiratory oxygen with $\mathrm{NO}$ and its carrier gas, nitrogen.

The effects on inspired $\mathrm{NO}$ and $\mathrm{NO}_{2}$ of the following manipulations to the ventilator and circuit were then tested against the standard set up. (1) Administration site: proximal extreme (PE) versus A. (2) Analysis site: inspiratory limb (A) or expiratory limb (C) versus B. (3) Ventilator gas flow rate: $51 / \mathrm{min}$ and $20 \mathrm{l} / \mathrm{min}$ versus $10 \mathrm{l} / \mathrm{min}$. (4) Inspiratory to expiratory (I:E) ratios: 1:3 versus $1: 1$.

Subsequently, we performed test lung ventilation with standard settings and NO concentrations from 10-100 ppm (increments of 10 $\mathrm{ppm}$ ) and measured $\mathrm{NO}_{2}$ at $\mathrm{B}$, initially in room air and then in $90 \%$ oxygen.

Finally, identical manipulations to administration site (A or PE), analysis site (B or C), and ventilator flow rates $(5,10,20)$ were applied to eight infants who were receiving inhaled NO at 20-40 ppm as part of a separate clinical trial. Hospital ethics committee approval and parental informed consent was obtained for each child.

\section{Results}

We found that the concentration of $\mathrm{NO}_{2}$ at the patient (site B) is independent of ventilator gas flow rate or I:E ratio. Addition of NO to the circuit before the humidifier led to a small $(-2 \%)$ decrease in $\mathrm{NO}$ and a small rise $(+2 \%)$ in $\mathrm{NO}_{2}$ at $\mathrm{B}$.

Site of analysis was important. $\mathrm{NO} / \mathrm{NO}_{2}$ values at $B$ and $C$ were almost identical, whereas those measured adjacent to $\mathrm{A}$ were $22 \%(\mathrm{NO})$ and $24 \%\left(\mathrm{NO}_{2}\right)$ higher than at $\mathrm{B}$.

During room air ventilation of the test lung, $\mathrm{NO}_{2}$ production was less than $5 \mathrm{ppm}$ for each $\mathrm{NO}$ concentration tested with $\mathrm{NO}_{2}$ reaching a plateau of $1.3 \mathrm{ppm}$ at $60-100 \mathrm{ppm}$ NO. In contrast, in $90 \%$ oxygen, production of $\mathrm{NO}_{2}$ increased incrementally, with $\mathrm{NO}_{2}$ exceeding 5 ppm between 70 and 80 ppm NO (table).

Studies of $\mathrm{NO}_{2}$ production in eight ventilated infants (aged 1-19 months) gave similar, reproducible results to those predicted from the test lung studies. In each case the observed $\mathrm{NO}_{2}$ was within $0.5 \mathrm{ppm}$ of the predicted $\mathrm{NO}_{2}$. Proximal NO administration, ventilator flow rate, and analysis at $\mathrm{B}$ or $\mathrm{C}$ did not influence $\mathrm{NO}_{2}$ production.

\section{Discussion}

Patients with cardiorespiratory disease who may potentially benefit from inhaled NO

$\mathrm{NO}_{2}$ (ppm) produced when $\mathrm{NO}$ is administered at concentrations of 10-100 ppm during standard ventilation in $21 \%$ and $90 \%$ oxygen. The upper limit of $\mathrm{NO}_{2}$ to avoid pulmonary toxicity is 5 ppm (see text)

\begin{tabular}{ccccccccccr}
\hline & \multicolumn{2}{l}{$N O(p p m)$} & & & & & & & & \\
\cline { 2 - 10 } & 10 & 20 & 30 & 40 & 50 & 60 & 70 & 80 & 90 & 100 \\
\hline $\begin{array}{c}\text { Oxygen: } \\
21 \% \\
90 \%\end{array}$ & 0.3 & 0.5 & 0.7 & 0.9 & 1.0 & 1.3 & 1.3 & 1.3 & 1.3 & 1.3 \\
\hline
\end{tabular}

usually require a high inspired oxygen concentration. On the basis of a known, predictable rate of NO oxidation, other authors have alerted clinicians to the potential for toxic $\mathrm{NO}_{2}$ concentrations in the presence of high oxygen. ${ }^{1819}$ Using our ventilator circuit and $90 \%$ oxygen, inhaled $\mathrm{NO} \geqslant 80 \mathrm{ppm}$ led to $\mathrm{NO}_{2}$ concentrations $>5 \mathrm{ppm}$ and thus may be toxic. However, our data support safe extended administration of NO at lower doses with steady state $\mathrm{NO}_{2}$ concentrations less than 5 ppm. The lower concentrations of $\mathrm{NO}_{2}$ observed in our study compared with previously published safety guidelines is almost certainly due to gas washout by continuous flow ventilation. Therefore, the data presented here more closely reflect clinical practice.

With respect to $\mathrm{NO}_{2}$ production, $\mathrm{NO}$ may be safely delivered proximally or distally to the inspiratory limb without needing to alter total gas flow rate. However, analysis for $\mathrm{NO}$ and $\mathrm{NO}_{2}$ concentrations must be performed at or just distal to the patient; more proximal analysis may yield spurious data. Inspired oxygen analysis should logically occur after addition of NO, but proximal to the patient. These guidelines would also be applicable to the spontaneously breathing patient provided that a normal non-rebreathing circuit with sufficient continuous gas flow is used.

Unfortunately, the measurement of NO and $\mathrm{NO}_{2}$ at site $\mathrm{B}$ or $\mathrm{C}$ does not necessarily reflect alveolar concentrations of these gases. Alveolar gases may have a higher $\mathrm{NO}_{2}$ content due to a longer exposure to oxygen, water vapour, and possibly additional endogenous NO. However, the $\mathrm{NO} / \mathrm{NO}_{2}$ data from chemiluminescence analysers represent an average value during a set sampling period and with our device, a given $\mathrm{NO}$ or $\mathrm{NO}_{2}$ value is a 10 second average sampled every 20 seconds. For this reason, chemiluminescence analysis, although accurate at steady state, is not currently suited to end tidal or alveolar sampling. A more rapid sampling rate would allow detection of phasic changes, but at a decreased level of precision.

Inhaled NO is an important new treatment for a variety of disorders in infants, children, and adults. Toxic $\mathrm{NO}_{2}$ production in high inspired oxygen is a major potential risk; however, careful attention to guidelines for delivery and monitoring will minimise this hazard.

Dr Miller and Dr Celermajer are supported by separate grants from the British Heart Foundation.

1 Furchgott RF, Zawadzki JV. The obligatory role of endothelial cells in the relaxation of arterial smooth muscle by thelial cells in the relaxation of arterial s

2 Ignarro LJ. Biological actions and properties of endothelium-derived nitric oxide formed and released from thelium-derived nitric oxide formed and

3 Palmer RMJ, Ferrige AG, Moncada S. Nitric oxide release accounts for the biological activity of endothelium-derived relaxing factor. Nature 1987; 327: 524-6.

4 Palmer RMJ, Ashton DS, Moncada S. Vascular endothelial cells synthesise nitric oxide from L-arginine. Nature 1988; 333: 664-66.

5 Frostell CG, Fratacci MD, Wain JC, Zapol WM. A selective pulmonary vasodilator reversing hypoxic pulmonary vasoconstriction. Circulation 1991; 83: 2038-47.

6 Ignarro LJ, Buga GM, Wood KS, Byrns RE, Chaudhuri G. Endothelium-derived relaxing factor produced and released from artery and vein is nitric oxide. Proc Natl Acad Sci USA 1987; 84: 9265-9.

7 Roberts JD, Polander DM, Lang P, Zapol WM. Inhaled nitric oxide in persistent hypertension of the newborn. Lancet 1992; 340: 818-9. 
8 Kinsella JP, Neish SR, Shaffer E, Abman SH. Low-dose inhalational nitric oxide in persistent pulmonary hypertension of the newborn. Lancet 1992; 340: 819-20.

9 Miller OI, James I, Elliott MJ. Intra-operative use of inhaled low dose nitric oxide. F Thorac Cardiovasc Surg 1993; 105: 550-1.

10 Haydar A, Malhere T, Mauriat P, et al. Inhaled nitric oxide for postoperative pulmonary hypertension in patients with congenital heart disease. Lancet 1992; 340: 1545.

11 Berner M, Beghetti M, Ricou B, Rouge JC, Prêtre R, Friedli B. Relief of severe pulmonary hypertension after closure of a large ventricular septal defect using low dose inhaled nitric oxide. Intensive Care Med 1993; 19: 75-7.

12 Selldén $\mathrm{H}$, Winberg P, Gustafsson LE, Lundell B, Böök K, Frostell CG. Inhalation of nitric oxide reduced pulmonary hypertension after cardiac surgery in a $3.2 \mathrm{~kg}$ infant. Anaesthesiology 1993; 78: 577-80.

13 Pepke-Zaba J, Higenbottam TW, Tuan Dinh-Xuan A Stone D, Wallwork J. Inhaled nitric oxide as a cause of selective pulmonary vasodilation in pulmonary hypertension. Lancet 1991; 338: 1173-4.

14 Rossaint R, Falke KJ, Lopez F, Slama K, Pison U, Zapol WM. Inhaled nitric oxide for the adult respiratory distress syndrome. N Engl f Med 1993; 328: 399-405.

15 Stavert DM, Lehnert BE. Nitrogen oxides and nitrogen dioxide as inducers of acute pulmonary injury when inhaled at relatively high concentrations for brief periods. Inhalation Toxicology 1990; 2: 53-67.

16 Scott EG, Hunt WB. Silo fillers disease. Chest 1973; 63: $701-6$.

17 Centers for Disease Control. Recommendations for occupational safety and health standard. MMWR 1988; 37 (suppl 7): 1-29.

18 Foubert L, Fleming B, Latimer R, et al. Safety guidelines for use of nitric oxide. Lancet 1992; 339: 1615-6.

19 Bouchet M, Renaudin MH, Raveau C Mercier JC, Dehan M, Zupan V. Safety requirements for use of Dehan M, Zupan V. Safety requirements for use of
inhaled nitric oxide in neonates. Lancet $1993 ; 341$ : 968-9. 